\title{
Path Analysis on the Effectiveness of Exclusive Breastfeeding Advocacy Program on Breastfeeding Practice using Theory of Planned Behavior
}

\author{
Valentina Dili Ariwati'1), Didik Tamtomo²), Endang Sutisna Sulaeman²) \\ 1) Masters Program in Public Health, Universitas Sebelas Maret, Surakarta \\ 2) Faculty of Medicine, Universitas Sebelas Maret, Surakarta
}

\begin{abstract}
Background: Exclusive breastfeeding coverage was $52.30 \%$ in 2015 , which was below the national target of 80\%. For the past few years Klaten local government has launched the Exclusive Breastfeeding Advocacy Program with the objective to increase exclusive breastfeeding coverage. This study aimed to determine the effectiveness of Exclusive Breastfeeding Advocacy Program using Theory of Planned Behaviour framework.

Subjects and Method: This was an analytic observational study with retrospective cohort design. This study was conducted from 2 August to 16 September 2016 in Klaten and Magelang, Central Java, Indonesia. A total of 200 lactating mothers of infants aged 6 to 12 months was selected for this study by multi-stage random sampling. The dependent variables were exclusive breastfeeding and intention. The independent variables were exclusive breastfeeding advocacy program, attitude, subjective norm, and perceived behavior control. The data were collected using a set of questionnaire, and analyzed by path analysis.

Results: The path model showed Goodness of Fit indices as follows: $\mathrm{CMIN}=4.24, \mathrm{p}=0.374$, $\mathrm{GFI}=0.99, \mathrm{NFI}=0.99, \mathrm{CFI}=1.00, \mathrm{RMSEA}=0.017$. Strong intention $(\mathrm{b}=0.15 ; \mathrm{p}<0.001)$ had direct effect on exclusive breastfeeding. Positive atittude $(b=0.27 ; p<0.001)$, positive subjective norm $(b=0.26 ; p<0.001)$, strong perception of behavior control $(b=0.25 ; p<0.001)$, and exclusive breastfeeding advocacy program $(b=0.36 ; p<0.001)$, had positive effects on intention.

Conclusion: Intention has direct effect on exclusive breastfeeding. Atittude toward exclusive breastfeeding, subjective norm, and perception of behavior control, have positive effects on intention. Exclusive breastfeeding advocacy program is effective in increasing the likelihood of providing exclusive breastfeeding.
\end{abstract}

Keywords: exclusive breastfeeding advocacy program, attitude, subjective norm, perceived behavior control, intention, exclusive breastfeeding behavior.

\section{Correspondence:}

Valentina Dili Ariwati. Masters Program in Public Health, Universitas Sebelas Maret. Jl. Ir. Sutami 36 A, Surakarta, Central Java. Email: valentinadilia92@gmail.com.

\section{BACKGROUND}

Exclusive breastfeeding is breast milk which is given to infants aged o-6 months without any complementary food, except drugs and vitamins. Complementary feeding can be given to babbies after 6 months of age and mothers also can continue breastfeeding until the babies are 2 years old (UNICEF Indonesia, 2012).
The Regulation of Ministry of Women Empowerment and Child Protection No.3 of 2010 states that exclusive breastfeeding has many benefits for babies, such as protecting babies from various infectious diseases and the composition of breast milk which is appropriate for the needs of babies at the beginning of birth. The benefit of breast milk for lactating mothers is increasing interactions between mother and 
baby (Arisman, 2010). The benefit for the family is saving household expenses. The benefit for the country is saving foreign exchange expenditure (Indonesian Perinatology Association, 2011).

Based on Basic Health Research in 2013, exclusive breastfeeding coverage was $38 \%$. It decreased compared to 2012, which was $61.50 \%$. The exclusive breastfeeding coverage in Indonesia in 2015 was $52.30 \%$ which was below the national target of $80 \%$ (Ministry of Health, 2014). Based on Indonesia Health Profile in 2012, Infant Mortality Rate (IMR) reached 34/100o live births, while the target of decreasing IMR by Ministry of Health was 23/1000 live births. The main causes of infant mortality are acute respiratory infections (ARIs), fever, and diarrhea which can be prevented by exclusive breastfeeding (Ministry of Health, 2013; Ministry of Women Empowerment and Child Protection No.3 of 2010).

The Central Java Provincial Health Office (2013) stated that one of three babies under six months was given exclusive breastfeeding. Exclusive breastfeeding in Central Java decreased in 2012 by $25.60 \%$ and in 2011 by $45.18 \%$ (Central Java Provincial Health Office, 2012).

The exclusive breastfeeding coverage in Klaten Regency in 2007 was $22.70 \%$ (Klaten Regency Health Office, 2008). Natural disasters had several impacts, including 3 out of 4 families with babies under 2 years of age got baby formula and porridge; the consumption of formula milk increased from $27.80 \%$ to $42.60 \%$; the incidence of diarrhea increased twice; and breast milk was not a priority for emergency and disaster management programs (Roekminto, 2014).

The Regional Government of Klaten Regency responded to the effect of natural disasters on exclusive breastfeeding by conducting Exclusive Breastfeeding Advo- cacy Program. Exclusive Breastfeeding Advocacy Program was pioneered by Gantiwarno Community Health Center through the Decision of the Head of Gantiwarno Health Center Number 440/110/14/12 regarding Exclusive Breastfeeding Advocacy Program. Exclusive Breastfeeding Advocacy Program involves husbands, families, communities, community leaders, and religious leaders. The Regional Government of Klaten Regency determined the The Regional Government of Klaten Regency Number 7 of 2008 about initiation of early initiation of exclusive breastfeeding, and implemented Exclusive Breastfeeding Advocacy Program in Klaten Regency (Klaten Regency Health Office, 2013; Roekminto, 2014).

Klaten Regency is the pioneer who created Exclusive Breastfeeding Advocacy Program in Indonesia. Exclusive breastfeeding coverage increased from $43.3 \%$ (2008) to $80.2 \%$ (2013). Data from Klaten Regency Health Office in 2013 to 2015 and the results of the previous study showed that there was an increase in exclusive breastfeeding coverage in several sub-districts. However, there was a decrease in exclusive breastfeeding coverage in several sub-districts year by year.

Based on the description above, it can be concluded that Exclusive Breastfeeding Advocacy Program is an external factor that affects the exclusive breastfeeding behavior. Meanwhile, the internal factors refer to the theory of planned behavior (TPB), such as attitude, subjective norm, perceived behavioral control, and intention (Ajzen, 1991).

This study aimed to analyze the effectiveness of Exclusive Breastfeeding Advocacy Program on exclusive breastfeeding behavior using Theory of Planned Behavior. 


\begin{tabular}{l}
\hline \multicolumn{1}{c}{ SUBJECTS AND METHOD } \\
\hline 1. Study Design \\
This study used an analytic observational \\
study with retrospective cohort design. This \\
study was conducted from August 2 to Sep- \\
tember 16, 2016, in Klaten and Magelang.
\end{tabular}

\section{Population an Sampling}

The population of the study consisted of 917 lactating mothers of infants aged 6-12 months. A total number of 200 lactating mothers were selected as the sample of this study by multi-stage random sampling.

\section{Study Instrument}

The study used a set of questionnaire for collecting the data.

\section{Data Analysis}

This study used path analysis IBM SPSS AMOS 22 for analyzing the data.

Table 1. The characteristic of subject of the study

\begin{tabular}{llcc}
\hline Characteristic & Criteria & Frequency & Percentage (\%) \\
\hline Age & $<$ 20 years & 1 & 0.50 \\
& 20-35 years & 168 & 84.00 \\
Occupation & 35 years & 31 & 15.50 \\
& Civil Servant & 4 & 2.00 \\
& Farmer & 14 & 7.00 \\
& Private Employee & 17 & 8.50 \\
Housewife & 147 & 73.50 \\
Entrepreneur & 17 & 8.50 \\
Education & Others & 1 & 0.50 \\
& Elementary school & 16 & 8.00 \\
& Junior High School & 48 & 24.00 \\
Senior High School & 109 & 54.50 \\
Family Income & 10 & 5.00 \\
Infant age & Bachelor & 16 & 8.00 \\
& Master/Doctorate Degree & 1 & 0.50 \\
& < minimum wage & 83 & 41.50 \\
& $\geq$ minimum wage & 117 & 58.50 \\
& 6 months & 36 & 18.00 \\
& 7 months & 27 & 13.50 \\
8 months & 30 & 15.00 \\
Infant status & 9 months & 37 & 18.50 \\
& 10 months & 28 & 14.00 \\
& 11 months & 24 & 12.00 \\
& 12 months & 18 & 9.00 \\
& First child & 75 & 37.50 \\
& Second child & 77 & 38.50 \\
& Third child & 33 & 16.50 \\
& Fourth child & 11 & 5.50 \\
& Fifth child & 2 & 1.00 \\
& $>5$ child & 2 & 1.00 \\
\hline
\end{tabular}

\section{RESULTS}

\section{The characteristic of subject of the study}

The result of the characteristic of subject of the study in table 1 shows that most of the 200 subjects of the study aged 20-35 years (84\%). Most of the subjects of the study did not work and only did housework (73.50\%). Most of the subjects of the study were Senior High School graduate (54.50\%). Most of the subjects of the study had $\geq$ minimum wage $(58.50 \%)$. Most of the subjects of the study had babies aged 9 months(18.50\%). Most of the subjects of the study had babies who were the second child (38.50\%). 
Most of the subjects of the study who received exposure of Exclusive Breastfeeding Advocacy Program were 107 subjects of the study (53.50\%). Most of the subjects of the study who had positive attitude were 108 study subjects (54 \%). Most of the subjects of the study who had high subjective norm were 105 subjects of the study (52.50\%). Most of the subjects of the study who had good perceived behavioral control were 103 subjects of the study (51.50\%). Most of the subjects of the study who had strong intention were 103 subjects of the study (51.50\%). Most of the subjects of the study who gave exclusive breastfeeding were 111 subjects of the study (55.50\%).

\section{Path Analysis}

This study used path analysis IBM SPSS AMOS 22 for analyzing the data. The initial model in path analysis consisted of several stages as follows:

a. Model Specification

The initial model in path analysis could be seen in Figure 1.

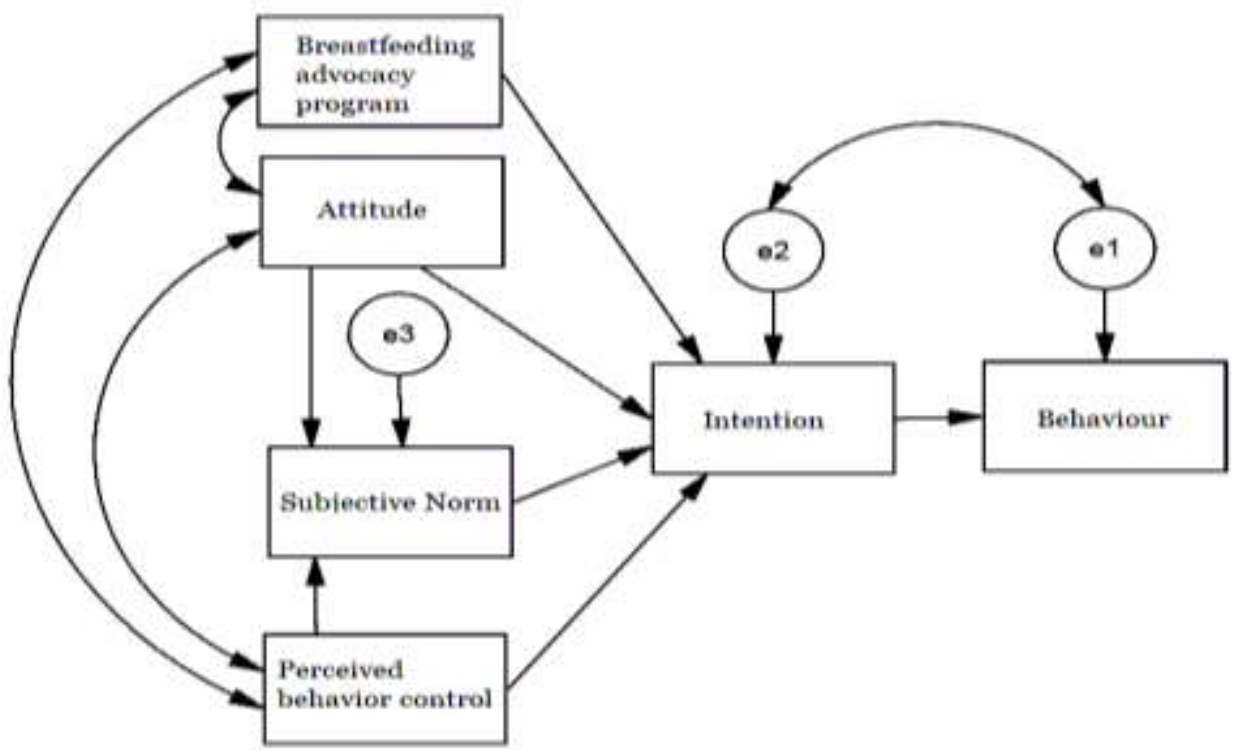

Figure 1. Structural Model

\section{b. Model Identification}

Measurement variables were 6, endogenous variables were 3 , exogenous variables were 3 , a total number of parameter was 11 . Degree of freedom $(\mathrm{df})=$ (a total number of measurement variables $\mathrm{x}$ (a total number of measurement variables +1 ) / 2 (endogenous variables + exogenous variables + a total number of parameter $)=(6 \times 7) / 2-(2+4+$ 11) $=4$. Model identification in this path analysis produced $\mathrm{df}$ value over identified which means that path analysis could be conducted.

c. Fit Model and Estimation of Parameter The suitability between path analysis model made by authors and the best variable cor- relation was checked. It was saturation model. This was made based on sample data collected by authors. Figure 2 shows the structural model after estimation using IBM SPSS AMOS 22. The indicator that shows the suitability of the path analysis model, as shown in table 2, also shows that there is a Goodness of Fit Measure. The result of CMIN fit index was 4.24 with $\mathrm{p}$ value $=0.374(>0.05)$; GFI $=0.99(>0.90) ; \mathrm{NFI}=$ 0.99 (>0.90); CFI 1.00 ( $>0.90)$; RMSEA = 0.017 (<0.05) which means that the empirical model meets the criteria specified and in accordance with empirical data. 


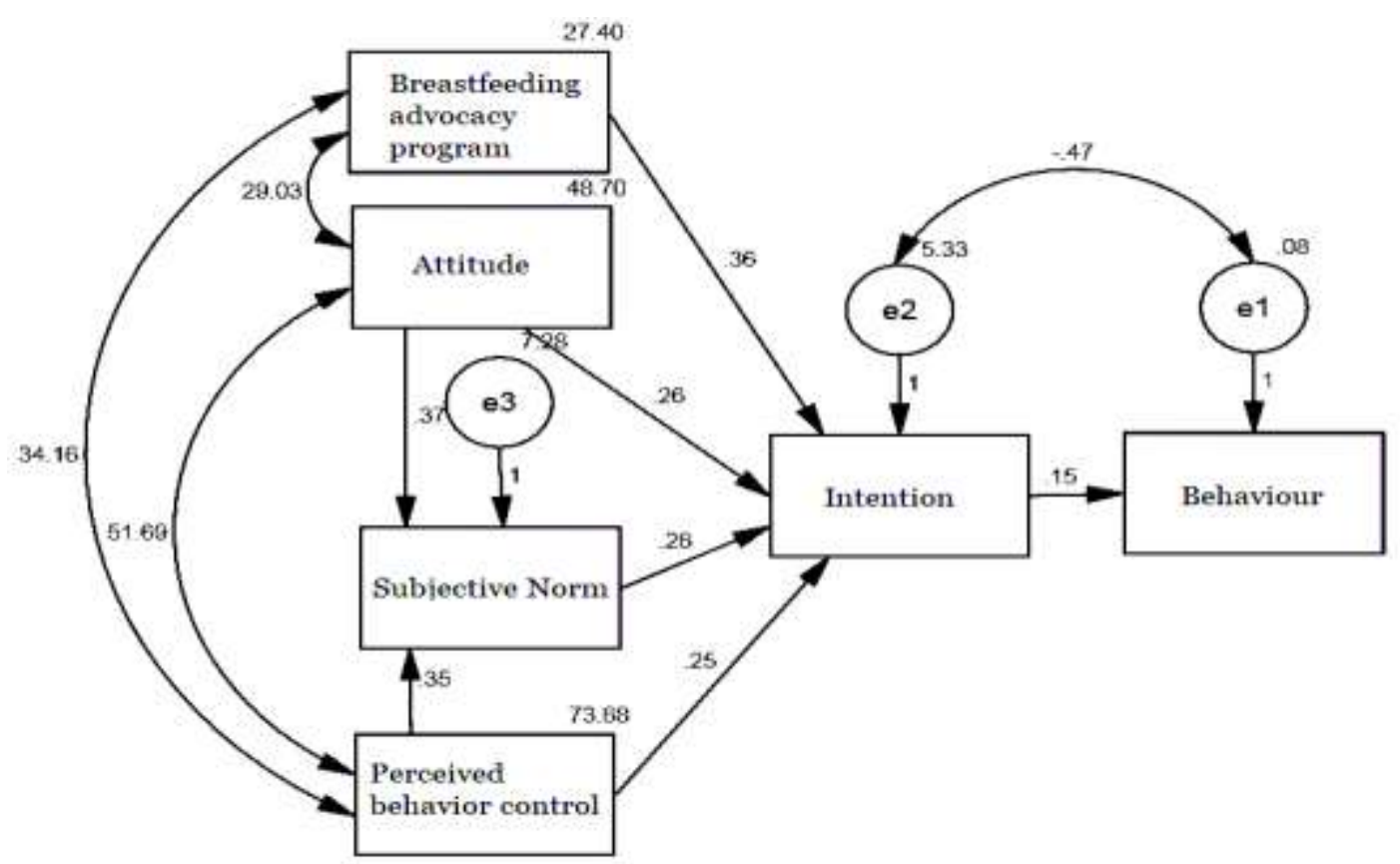

Figure 2. The structural mdoel with unstandarized

Table 2. The result of path analysis on the effectiveness of exclusive breastfeeding advocacy program on breastfeeding practice using theory of planned behavior

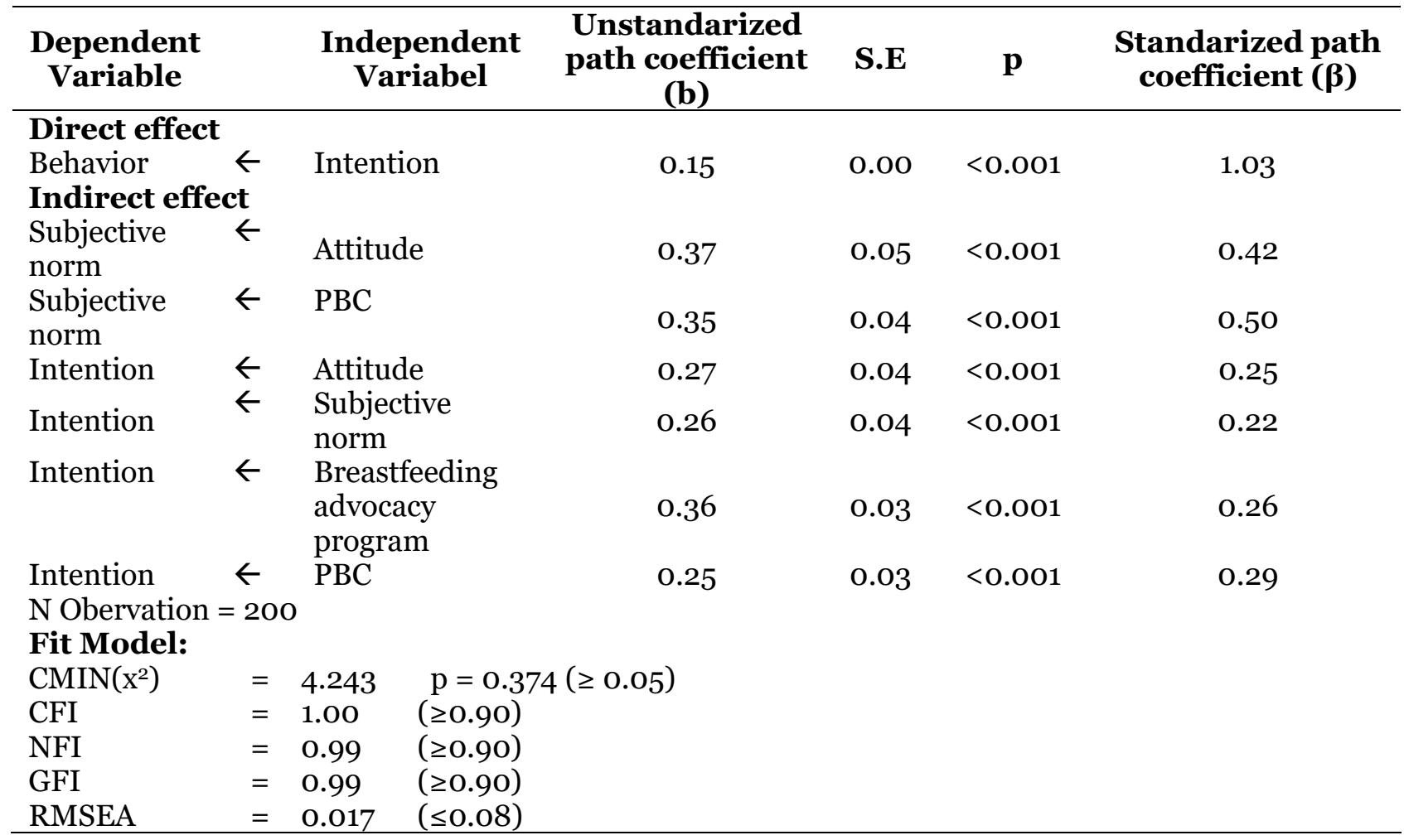

Table 2 shows that the non-standardized path coefficient values were obtained based on the result of calculation using IBM SPSS AMOS 22 computer software pro- gram. There was positive association between attitude and subjective norm $(b=$ $0.37 ; \mathrm{SE}=0.05 ; \mathrm{p}<0.001)$. It indicated that 
each increase in 1 unit attitude score would increase subjective norm score by 0.37 .

There was positive association between attitude and intention $(b=0.27$; $\mathrm{SE}=0.04 ; \mathrm{p}<0.001)$. It indicated that each increase in 1 unit attitude score would increase intention score by 0.25 units.

There was positive association between exclusive breastfeeding advocacy program and intention $(b=0.36 ; \mathrm{SE}=0.03$; $\mathrm{p}<0.001)$. These result indicated that each increase in 1 unit exclusive breastfeeding advocacy program score would increase intention score by 0.36. Exclusive breastfeeding advocacy program was effective in increasing exclusive breastfeeding behavior through intention.

There was positive association between intention and exclusive breastfeeding behavior $(\mathrm{b}=0.15 ; \mathrm{SE}=0.01 ; \mathrm{p}<0.001)$. It indicated that exclusive breastfeeding advocacy program was effective in increasing exclusive breastfeeding behavior.

There was positive association between perceived behavioral control and intention $(b=0.25 ; \mathrm{SE}=0.03 ; \mathrm{p}<0.001)$. Iit indicated that each increase in 1 unit perceived behavioral control score would increase intention score by 0.25 .

d. Model Respecification

The model in this study was in accordance with the sample data which was shown by the saturation model and the path coefficient which was more than zero and statistically significant. Therefore, it was not necessary to recreate the path analysis model.

\section{$\frac{\text { DISCUSSION }}{\text { 1. The correlation between exclusive }}$ breastfeeding advocacy program and exclusive breastfeeding beha- vior through intention}

There was an indirect correlation between Exclusive Breastfeeding Advocacy Program and exclusive breastfeeding behavior through intention as intervening variable.

According to Asriani and Itriyati (2009), exclusive breastfeeding advocacy program is an innovation program that uses health promotion and health education. Exclusive Breastfeeding Advocacy Program can increase exclusive breastfeeding coverage in Klaten Regency. The Ministry of Health (2006) stated that health knowledge can be improved through one effective effort, namely health promotion. Health promotion can involve the role of religious leaders and community leaders, for example, giving health promotion about exclusive breastfeeding as one of the materials provided by the Ministry of Religious Affairs to the bride and groom when giving marriage counseling. Good knowledge will bring good health behavior.

According to Fishbein and Ajzen (1975), intention is a stage of preparation of individuals to conduct behavior. Intention becomes the main predictor of behavior before having an opportunity to conduct behavior in a real way. TPB explains that intention is a direct factor of individual behavior.

Based on the description above, it can be concluded that there is an indirect positive correlation between Exclusive Breastfeeding Advocacy Program and exclusive breastfeeding behavior through intention. Therefore, Exclusive Breastfeeding Advocacy Program is effective to improve exclusive breastfeeding behavior; thus, the result is in accordance with previous studies and existing theories.

\section{The correlation between attitude and exclusive breastfeeding beha- vior through intention}

There was an indirect correlation between attitude and exclusive breastfeeding behavior through intention. 
Journal of Health Promotion and Behavior (2016), 1(3): 150-160

https://doi.org/10.26911/thejhpb.2016.01.03.02

Based on a study conducted by Young and Anne (2015), attitude is positively related to the intention in giving exclusive breastfeeding to infants aged 3 months $(\beta=$ 0.34; $\mathrm{p}<0.001)$ and to infants aged 6 months $(\beta=0.30 ; p<0.01)$. Attitude also affects the maternal intention in giving exclusive breastfeeding until the baby is 1 year old $(\beta=0.28 ; p<0.001)$.

Based on a study conducted by Mutuli and Walingo (2014), attitude affects the intention of lactating mothers in giving exclusive breastfeeding $(\beta=0.86 ; p<0.001)$.

Intention significantly affects exclusive breastfeeding $(\beta=0.26 ; \mathrm{p}<0.001)$. According to Akour et al. (2010), mothers who have positive attitude on breastfeed tend to have good intentions in breastfeeding their babies exclusively. Lupton and Fenwick (2001) states that lactating mothers need to sacrifice for their children as a chalange. Mothers need strength in the form of positive attitude, high confidence, and high self-confidence to be able to face these challenges. As a result, intention will be formed and will make mother more convinced of her decision to breastfeed her baby. Intention is a form of concern of a mother on the health and safety of her baby. It affects mothers behavior to do the hopes, plans, and challenges of mother in breastfeeding her babies.

Based on the description above, it can be concluded that there is an indirect positive correlation between attitude and exclusive breastfeeding behavior through intention. Therefore, the result is in accordance with previous studies and existing theories.

3. The correlation between attitude and exclusive breastfeeding behavior through subjective norm and intention

There was an indirect correlation between attitude and exclusive breastfeeding beha- vior through subjective norm and intention as intervening variables.

The result of this study is in accordance with the opinion of IDAI (2009) and Infact Canada (2010) which states that the ability of mothers to breastfeed will increase if mother has positive attitude and high confidence. Mothers who are persistent will be aware of their strengths and weaknesses, but they are able to make decisions honestly and purely.

Based on a study conducted by Kurniawati and Hargono (2014), the positive and negative attitudes of mothers about exclusive breastfeeding will determine the decision of mothers in giving exclusive breastfeeding. Attitude is affected by the mother's beliefs and perceptions on people around her, such as the influence of friends who give exclusive breastfeeding will make the mother assumes that this friend supports the mother in giving exclusive breastfeeding. Ajzen (1991) states that one's perception on support and social pressure in the environment is subjective norm.

Based on the description above, it can be concluded that there is an indirect positive correlation between attitude and exclusive breastfeeding behavior through subjective norm and intention. Therefore, the result is in accordance with previous studies and existing theories.

\section{The correlation between subjective norm and exclusive breastfeeding behavior through intention}

There was an indirect correlation between subjective norm and exclusive breastfeeding behavior through intention as intervening variable.

Mothers who get influence from people around them for not giving complementary food to babies before 6 months of age, will have a tendency to succeed in giving exclusive breastfeeding. The mother's assumption on social support and acceptance of 
breastfeeding will help her make the decision for giving or not giving exclusive breastfeeding (Hamilton et al, 2011).

Behara and Kumar (2015) state that intention and self-confidence affect the breast milk, which have a greater chance in providing exclusive breastfeeding successfully. This opinion is in accordance with the theory of Ajzen (1991) which states that intention is the main predictor of behavior.

Based on the description above, it can be concluded that there is an indirect positive correlation between subjective norm and exclusive breastfeeding behavior through intention. Therefore, the result is in accordance with previous studies and existing theories.

\section{The correlation between perceived behavior control and exclusive breastfeeding behavior through intention}

There was an indirect correlation between perceived behavioral control and exclusive breastfeeding behavior through intention as intervening variable.

Based on a study conducted by Puspita (2015), the increase of maternal perceived behavioral control affects intention of mothers to give exclusive breastfeeding from low intention (20\%) and enough intention (80\%) to high intention (100\%). A study conducted by Mutuli and Walingo (2014) states that perceived behavioral control directly affects the intention to breastfeed with $\mathrm{p}$ value by $<0.05$.

Study conducted by Agumadu et al. (2016), mothers who have good perceptions on breastfeeding have a greater chance in providing exclusive breastfeeding successfully than mothers who have poor perceptions. Mothers who have good perceptions of exclusive breastfeeding have double chance to breastfeed exclusively compared to mothers who do not have good perception of exclusive breastfeeding $(\mathrm{OR}=2.29 ; \mathrm{p}$
$<0.001)$ in lactacting mothers with $3^{-}$ month-old infants; $(\mathrm{OR}=2.49 ; \mathrm{p}<0.001)$ in lactacting mothers with 6-month-old infants.

Based on the description above, it can be concluded that there is an indirect positive correlation between perceived behavioral control and exclusive breastfeeding behavior through intention. Therefore, the result is in accordance with previous studies and existing theories

\section{The correlation between perceived behavioral control and exclusive breastfeeding behavior through subjective norm and intention}

There was an indirect correlation between perceived behavioral control and exclusive breastfeeding behavior through subjective norm and intention as intervening variables

The experience of mother in breastfeeding, the observation of mother on her environment, and the information obtained by the mother will affect mother's perception of breastfeeding. Perception about breastfeeding will determine the mother's assessment of people around her (Kurniawati and Hargono, 2014). A study conducted by Giles et al. (2007) shows that subjective norm affect the intention of adolescents to give breast milk to their future babies with $\mathrm{p}$ value by $<0.001$, both teenage girls and boys.

According to Fishbein and Ajzen (1975), behavior is based on intention factor which are stages of consideration or planning to take or do not take any action. It refers as individual intentions before doing a behavior. Intention is the main predictor of behavior.

Based on the description above, it can be concluded that there is an indirect positive correlation between perceived behavioral control and exclusive breastfeeding behavior through subjective norm and inten- 
tion. Therefore, the result is in accordance with previous studies and existing theories.

\section{The direct correlation between in- tention and exclusive breastfeeding behavior}

There was a direct correlation between intention and exclusive breastfeeding behavior. Based on study conducted by Donnan et al (2013), intentions affect maternal behavior to breastfeed. The mother's intention to breastfeed which appears during pregnancy is the strongest predictor to breastfeed her baby $(\mathrm{p}=0.026)$.

According to Compton (2005), the success of breastfeeding is affected by the mother's high self-awareness of the woman's duty, namely breastfeeding. Selfawareness which arises before labor is a strong predictor for successful breastfeeding. This is called intention. Strong intention will increase the chances of successful breastfeeding. According to Ajzen (1991), behavior is preceded by intention as the main predictor of behavior.

Based on the description above, it can be concluded that there is a positive correlation between intention and exclusive breastfeeding behavior. Therefore, the result is in accordance with previous studies and existing theories.

Exclusive breastfeeding advocacy program, attitude, subjective norm, and perceived behavioral control indirectly affected exclusive breastfeeding behavior through intention. Intention directly affects exclusive breastfeeding behavior. As a result, exclusive breastfeeding advocacy program is effective in increasing exclusive breastfeeding behavior using Theory of Planned Behaviour.

\section{REFERENCE}

Agumadu UH, Racine EF, Laditka SB, Coffman MJ (2016). Associations between perceived value of exclusive breastfee- ding among pregnant women in the united states and exclusive breastfeeding to three and six months postpartum: a prospective study. International Breastfeeding Journal. 11(8): 1-10.

Ajzen I (1991). The theory of planned behavior. Organizational behavior and human decision processes. 50(1): 179211.

Akour NA, Khassawneh MY, Khader YS, Ababneh AA, Haddad AM (2010). Factor affecting intention to breastfeed among syrian and jordanian mothers: a comparative cross-sectional study. International Berastfeeding Journal. 5 (6): 1-8.

Arisman (2010). gizi dalam daur kehidupan. Jakarta: EGC.

Asriani DD, Itriyati F (2009). Gerakan inisiasi menyusui dini dan pemberian asi eksklusif kabupaten klaten. Retrieved from http://igi.fisipol.ugm.ac.id. May 3, 2016.

Behera D, Kumar KA (2015). Predictors of Exclusive Breastfeeding Intention Among Rural Pregnant Women in India: A Study using theory of planned behavior. The international electronic journal of rural and remote health, education, practice, and policy. 15 (3405): 1-10.

Compton WC (2005). positive psychology. usa: wadsworth.

Dignam (1995). Understanding intimacy as experienced by breastfeeding women. health care for women international. 16 (5): 477-485.

Central Java Health Office. (2013). Buku profil kesehatan provinsi jawa tengah tahun 2012. Semarang: Dinas Kesehatan Provinsi Jawa Tengah.

Klaten Regency Health Office (2008). Buku profil kesehatan kabupaten klaten tahun 2007. Klaten: Dinas Kesehatan Kabupaten Klaten. 
Klaten Regency Health Office (2013). buku profil kesehatan kabupaten klaten tahun 2012. Klaten: Dinas Kesehatan Kabupaten Klaten.

Klaten Regency Health Office (2014). Buku Profil Kesehatan Kabupaten Klaten Tahun 2014. Klaten: Dinas Kesehatan Kabupaten Klaten.

Klaten Regency Health Office (2015). Buku profil kesehatan kabupaten klaten tahun 2014. Klaten: Dinas Kesehatan Kabupaten Klaten.

Ministry of Health (2006). Pedoman inisiasi menyusui dini. Jakarta: Departemen Kesehatan Republik Indonesia.

Donnan PT, Dalzell J, Symon A, Rauchhaus P, Hodge EM, Kellet G, Wyatt JC, Whitford HM (2013). Prediction of initiation and cessation of breastfeeding from late pregnancy to 16 weeks: The Feeding Your Baby (FYB) Cohort Study. BMJ Open. 3 (3274): 1-10.

Fishbein M, Ajzen I (1975). Belief, attitude, intention, and behavior: an introduction to theory and research. philippines: Addison-Wesley Publishing Company.

Giles M, Connor S, McClenahan C, Mallett J, Stewart-Knox B, Wright M (2007). Measuring young people's attitude to breasfeeding using the theory of planned behavior. Journal of Public Health. 29 (1): 17-26.

Hamilton K, Daniels L, White KM, Murray M, Walsh A (2011). Predicting mothers' decisions to introduce complementary feeding at 6 months. an investigation using an extended theory of planned behaviour. Appetite. 56 (3): 674-681.

Indonesian Pediatric Association (2009). air susu ibu dan tumbuh kembang anak. Retrieved from http://www.idai.or.id. March 10, 2016.
Infact Canada (2010). Breastfeeding. Retrieved from http://www.infactcanada. on March 10, 2016.

Ministry of Health (2014). Riset Kesehatan Dasar (RISKESDAS) 2013. Jakarta: Kementerian Kesehatan Republik Indonesia.

Ministry of Health (2013). Profil Kesehatan Indonesia 2012. Jakarta: Kementerian Kesehatan Republik Indonesia.

Ministry of Health (2014). Pusat Data dan Informasi Kementerian Kesehatan Republik Indonesia. Jakarta: Kementerian Kesehatan Republik Indonesia.

Ministry of Women Empowerment and Child Protection (2010). penerapan sepuluh langkah menuju keberhasilan menyusui. Jakarta: Kementerian Pemberdayaan Perempuan dan Perlindungan Anak.

Kurniawati D, Hargono R (2014). faktor deerminan yang mempengaruhi kegagalan pemberian asi eksklusif pada bayi usia 6-12 bulan di kelurahan mulyorejo wilayah kerja Puskesmas Mulyorejo Surabaya. Jurnal Promkes. 2(1): 15-27.

Lupton D, Fenwick J (2001). they've forgotten that i'm the mum: constructing and practicing motherhood in special care nurseries. Social Science \& Medicine. 53: 1011-1021.

Mutuli LA, Walingo MK (2014). Appicability of theory of planned behavior in understanding breastfeeding intention of postpartum women. International journal of multidisciplinary and current research. 2: 258-266.

Indonesian Perinatology Asociation (2011). Manajemen laktasi. jakarta: perkumpulan perinatologi indonesia.

Puspita YA (2015). perbedaan persepsi kontrol diri ibu hamil terhadap intensi ibu untuk memberikan ASI eksklusif pada kelas ibu hamil plus di puskes- 
Journal of Health Promotion and Behavior (2016), 1(3): 150-160

https://doi.org/10.26911/thejhpb.2016.01.03.02

mas Muara Teweh Kabupaten Barito Utara. Jurnal Edu Health. 5(2): 123130.

Roekminto R (2012). Upaya peningkatan program ASI di Kabupaten Klaten. dinkesklatenkab.com. Retreived on March 22016.

Surat Keputusan Kepala PPKKS Gantiwarno Nomor 440/110/14/12 tentang Program Kawal ASI.

UNICEF Indonesia (2012). Ringkasan kajian kesehatan ibu dan anak., dari http://www.unicef.org/indonesia/id/a5_b_ringkasan_kajian_kesehatan _rev.pdf/. Retrieved on March 13, 2016.

Young J, Anne E (2015). what to expect when you're expecting: communication, body image, and breastfeeding decisions. north carolina: communication, rhetoric, and digital media. 